\title{
Autoimmune channelopathies: new antibody-mediated disorders of the central nervous system
}

\author{
Angela Vincent
}

Address: Department of Clinical Neurology, Weatherall Institute of Molecular Medicine, John Radcliffe Hospital, Oxford OX3 9DS, UK

Email: angela.vincent@imm.ox.ac.uk

FI000 Biology Reports 2009, I:6I (doi:10.34I0/BI-6I)

The electronic version of this article is the complete one and can be found at: http://FI000.com/Reports/Biology/content/I/6I

\begin{abstract}
Contrary to established wisdom, there now appear to be antibody-mediated central nervous system (CNS) disorders. Over the last few years, a number of patients have been defined with antibodies to voltage-gated (VGKC) or ligand-gated (NMDAR, GlyR) ion channels or ungated water (AQP4) channels. Some of the disorders improve spontaneously over time, others may be more chronic and relapsing-remitting, but immunotherapies reduce antibody levels and improve clinical outcomes. These are exciting developments that herald a new era of immunotherapy-responsive CNS diseases, and they raise interesting questions regarding the aetiological and pathogenic mechanisms mediating these conditions.
\end{abstract}

\section{Introduction and context}

Autoimmune channelopathies are becoming one of the exciting areas of neurological diseases in clinical practice because, though relatively uncommon (collectively perhaps 20 per million per year), diagnosis of these conditions usually indicates a significant clinical improvement following immunotherapies that reduce autoantibody levels. The field stems from three decades of research into myasthenia gravis and the LambertEaton myasthenic syndrome $[1,2]$; in these conditions, autoantibodies to muscle nicotinic acetylcholine receptors (AChRs) or voltage-gated calcium channels (P/Qtype), respectively, are the main pathogenic agents and cause destruction and/or downregulation of their targets, leading to neuromuscular junction transmission failure (Table 1) which can be demonstrated in animal models. Newer disorders of peripheral neurotransmission include (a) peripheral nerve hyperexcitability syndromes with antibodies binding to ${ }^{125} \mathrm{I}$-dendrotoxin-labelled shaker-type (Kv1) voltage-gated potassium channels (VGKCs) extracted from mammalian cortex [3] and (b) autonomic neuropathies with antibodies to ${ }^{125}$ I-epibatidine-labelled ganglionic nicotinic AChRs [4].
Over the last decade or so, a new family of antibodyassociated diseases has emerged that is beginning to overturn previous concepts that regarded the brain as immune-privileged and protected by an impermeable blood-brain barrier. First, glutamate receptor (GluR3) antibodies were present in children with the very rare but devastating form of epilepsy called Rasmussen encephalitis [5], but these findings were not always confirmed in other cohorts of patients [6], and the main pathology is now thought to be cellular rather than antibody-driven [7]. The paradigm shift really began with the finding of very high VGKC antibody levels in patients with limbic encephalitis - which includes seizures, psychological disturbance, memory loss and high signal on magnetic resonance imaging (MRI) in the medial temporal lobes who responded convincingly to immunotherapies such as plasma exchange (which removes circulating plasma components such as antibodies and replaces them with substitute plasma proteins; see Figure 1) [8-10]. Until then, limbic encephalitis was almost always recognised as 'paraneoplastic' (that is, associated with a T cellmediated immune response to a tumour [11]) and with a poor response to treatments. The VGKC 
Table I. Peripheral nervous system autoimmune channelopathies

\begin{tabular}{|c|c|c|c|c|}
\hline & Myasthenia gravis & $\begin{array}{l}\text { Lambert-Eaton myasthenic } \\
\text { syndrome }\end{array}$ & $\begin{array}{l}\text { Peripheral nerve } \\
\text { hyperexcitability syndromes }\end{array}$ & Autonomic neuropathy \\
\hline Typical symptoms & Muscle weakness and fatigue & Muscle weakness & Muscle twitching, cramps, sweating & $\begin{array}{l}\text { Hypotension, constipation, } \\
\text { papillary abnormalities, sicca } \\
\text { syndrome (dry eyes and } \\
\text { mouth) }\end{array}$ \\
\hline Target & Muscle nicotinic $\mathrm{AChR}$ & VGCC P/Q-type & $\begin{array}{l}\text { Dendrotoxin-binding VGKC KvI.I, } \\
\mathrm{I} .2 \text {, I.6 complexes extracted from } \\
\text { mammalian cortex }\end{array}$ & $\begin{array}{l}\text { Ganglionic nicotinic AChR } \\
\text { (alpha 3) }\end{array}$ \\
\hline $\begin{array}{l}\text { Tumour association } \\
\text { or other pathology }\end{array}$ & $\begin{array}{l}\text { Thymoma, thymic } \\
\text { hyperplasia or idiopathic }\end{array}$ & $\begin{array}{l}\text { Small-cell lung cancer } \\
\text { common in adults (about 50\%) }\end{array}$ & $\begin{array}{l}\text { Thymoma, small-cell lung cancer } \\
\text { in about } 20 \%\end{array}$ & $\begin{array}{l}\text { Small-cell lung cancer or } \\
\text { other tumours uncommon }\end{array}$ \\
\hline $\begin{array}{l}\text { Main pathogenic } \\
\text { mechanism }\end{array}$ & $\begin{array}{l}\text { Complement-mediated } \\
\text { damage, increased AChR } \\
\text { degradation, some direct } \\
\text { block of AChR function }\end{array}$ & $\begin{array}{l}\text { Increased VGCC degradation, } \\
\text { no evidence of complement- } \\
\text { mediated damage }\end{array}$ & $\begin{array}{l}\text { Probably increased VGKC } \\
\text { degradation with no apparent } \\
\text { complement-mediated damage }\end{array}$ & $\begin{array}{l}\text { Direct block of function and } \\
\text { increased degradation }\end{array}$ \\
\hline Disease course & $\begin{array}{l}\text { Usually chronic, rare } \\
\text { spontaneous remissions }\end{array}$ & $\begin{array}{l}\text { Usually chronic, may improve } \\
\text { with tumour removal }\end{array}$ & $\begin{array}{l}\text { Can be chronic or monophasic, } \\
\text { postinfectious or postallergic }\end{array}$ & $\begin{array}{l}\text { Monophasic or chronic, } \\
\text { postinfectious }\end{array}$ \\
\hline
\end{tabular}

AChR, acetylcholine receptor; VGCC, voltage-gated calcium channel; VGKC, voltage-gated potassium channel.

antibody-associated central nervous system (CNS) phenotypes are now recognised widely, are usually nonparaneoplastic and include patients with some form of epilepsy [12,13] or Morvan syndrome [14]. However, despite colocalisation with antibodies to different Kv1 subtypes on brain tissue and in transfected HeLa cells expressing different Kv1 subtypes, the specificity of the antibodies is not altogether clear [15]; a new finding is that many of the antibodies bind not to the Kv1s themselves but to other juxtaparanodal proteins, such as contactin-associated protein 2 (Caspr2), that form part of the VGKC complex after extraction from brain tissue. Antibodies to Caspr2 are particularly frequent in patients with Morvan syndrome (S Irani, S Alexander, A Vincent, unpublished data).

\section{Major recent advances}

Some patients presenting with symptoms of cognitive problems, psychiatric disturbance or epilepsy were found to have antibodies that bound to the proximal dendrites of the hippocampal neuropil [16], distinct from the binding of VGKC antibodies more distally $[8,16]$; many of these antibodies were subsequently shown to be directed against $N$-methyl-D-aspartate receptors (NMDARs) (NR1/NR2B) [17], with NR1 as the main target [18]. Most of these patients progressed to a more complex phenotype with movement disorders or catatonia, mutism, sleep disturbance and autonomic dysfunction $[17,18]$. At first, the syndrome was associated with ovarian teratomas in young women, but in these cases, unlike the traditional paraneoplastic disorders [11], the conditions improved when the tumour was removed and immunotherapies given [17]. Now many nonparaneoplastic cases are being identified and the phenotype is widening to include both male and female adults, teenagers, and even young children $[18,19]$
(S Irani, A Vincent, unpublished data). These NMDAR antibodies may be different from those measured by binding to linear peptide sequences of NR2A/NR2B seen in neuropsychiatric patients [20] and have the potential to be pathogenic since they target extracellular domains on NR1/NR2B transfected human embryonic kidney cells and substantially reduce the expression of these subunits in primary cultures of hippocampal neurons [18]. The NMDAR antibodies were most easily detected in the cerebrospinal fluid (CSF) (at 1:10) compared with serum (at 1:400), and there is substantial intrathecal synthesis of the specific antibody [18] (Table 2); nevertheless, in absolute terms, serum levels are higher than CSF levels. Recently, antibodies to AMPAR ( $\alpha$-amino-3hydroxy-5-methyl-4-isoxazolepropionic acid receptor) GluR1/GluR2 were identified in another form of limbic encephalitis that was mostly cancer-related. These patients also showed treatment responses but tended to relapse [21].

Meanwhile, a completely different condition was found to be associated with antibodies to a water channel. Neuromyelitis optica (NMO, or Devic disease) has usually been considered to be part of the spectrum of inflammatory demyelinating disorders, of which multiple sclerosis is the best known. However, NMO is a distinct inflammatory condition of the optic nerves which involves severe visual failure and inflammation of the spinal cord causing longitudinally extensive transverse myelitis (at least three spinal cord segments with high signal on MRI), that leads to para- or tetraparesis, sensory deficits and bladder disturbances. Patients show variable recovery with immunomodulatory treatments but accumulate disability over time, and mortality is high if the disease is not appropriately treated [22]. In 2004, antibodies binding around small vessels, under 
Figure I. Aspects of the new autoimmune channelopathies

(a)

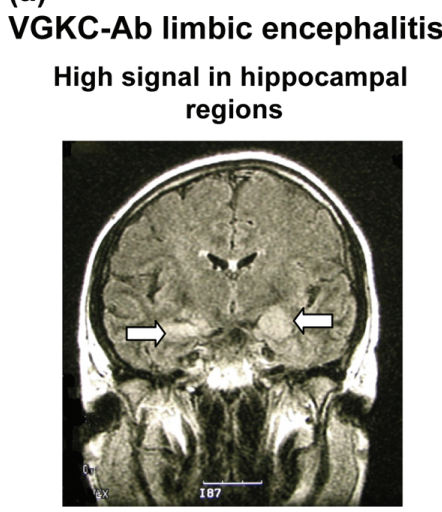

Antibodies to VGKC identified by immunoprecipitation of 125I-alpha-dendrotoxin-VGKCs in patient with limbic encephalitis

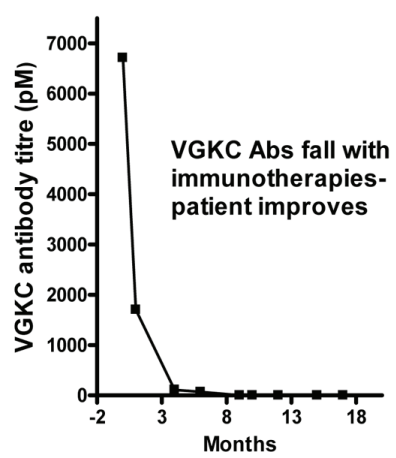

\section{(b)}

\section{NMDAR-Ab encephalitis}

Patient's serum IgG $(1: 40)$ binding to NR1/NR2b/EGFP transfected cells
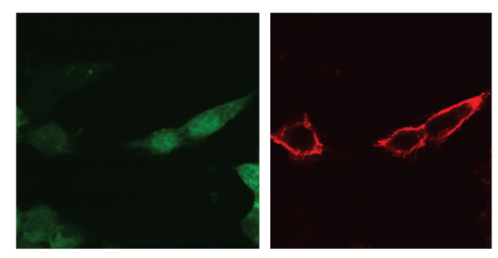

Patient's serum IgG (1:250) binding to 17 day live RAT hippocampal neurons

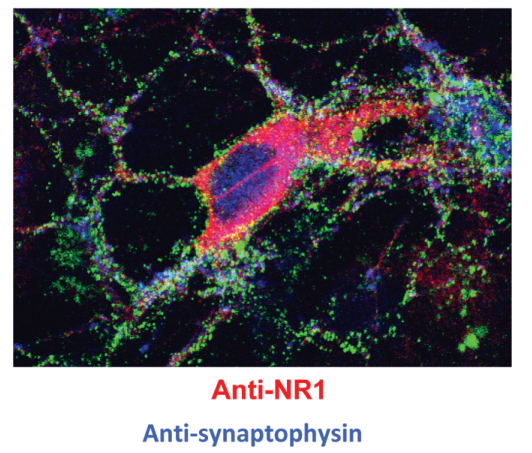

(c)

\section{Neuromyelitis optica}

Patient's serum IgG $(1: 20)$ binding to AQP-4-EGFP expressing cells
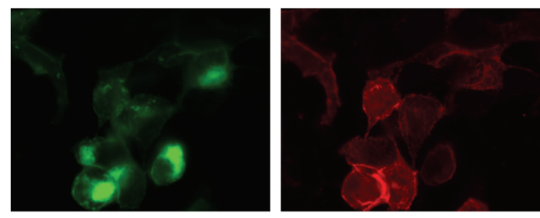

Antibodies to AQp4 identified by immunoprecipitation of EGFP-tagged AQP4

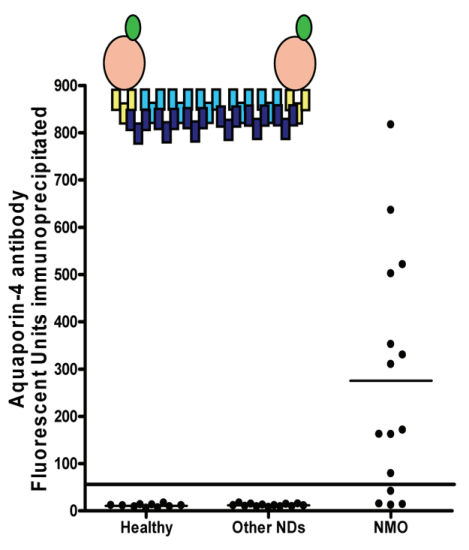

(a) Above, magnetic resonance imaging evidence of hippocampal inflammation and swelling (arrows) in a patient with voltage-gated potassium channel (VGKC) antibodies. Below, graph of dramatic decrease in the antibodies after successful treatment in another patient. (b) In the images above, antibodies (red anti-human $\operatorname{lgG}$ ) bind to human embryonic kidney cells expressing $\mathrm{N}$-methyl-D-aspartate receptors (NMDARs) (coexpressed with enhanced green fluorescent protein [EGFP]; some cells express EGFP without detectable NMDARs) in a young girl who developed an encephalopathy with mutism and catatonia and made a complete recovery after immunotherapies (see [32] and the video available online). In the image below, NMDAR antibodies (green) bind to unpermeabilised hippocampal neurons in culture, which were then fixed, permeabilised and stained for synaptophysin (blue) and NRI (red) (the binding of antibodies to the live cell surface does not colocalise well with the intracellular NRI which appears throughout the neuron). (c) In the images above, antibodies to aquaporin-4 (AQP4) in a patient with neuromyelitis optica (NMO) bind to cells transfected with AQP4-EGFP. In this case, the directly tagged AQP4-EGFP can also be solubilised from the cells and, as seen in the graph, the antibodies can be measured quantitatively by counting the fluorescence in the immunoprecipitates [34]. In these assays, sera from healthy individuals and from patients with unrelated diseases are negative. Ab, antibody; NDs, neurological diseases. Images courtesy of S Irani, L Zuliani, MI Leite, P Waters and B Lang.

the pia and in Virchow-Robin spaces were defined by immunofluoresence [23], and the target was subsequently identified as aquaporin-4 (AQP4), the only water channel expressed strongly in the brain (and also in kidney and stomach) [24]. Antibodies to AQP4 bind to the astrocyte endfeet that abut CNS blood vessels and are thought to be important contributors to the integrity of the blood-brain barrier. The antibodies lead to substantial loss of surface AQP4 by internalisation and activate complement with formation of the membrane attack complex, leading to cellular damage [25]. They also reduce astrocyte expression of excitatory amino acid transporter 2 (EAAT2) with reduced reuptake of glutamate [26] and hence potential excitotoxic damage. Interestingly, it seems that AQP4 and EAAT2 are part of a macromolecular complex [25]. Whether these changes alone lead to the substantial inflammatory infiltrates, areas of demyelination, loss of AQP4 and sometimes necrosis that are found in lesions $[27,28]$ is not yet clear, but increases in antibody levels are associated with clinical relapses, and AQP4 antibodies decrease in parallel with clinical improvement after 
Table 2. Central nervous system autoimmune channelopathies

\begin{tabular}{|c|c|c|c|c|c|}
\hline Examples & $\begin{array}{l}\text { VGKC-Ab-limbic } \\
\text { encephalitis }\end{array}$ & $\begin{array}{l}\text { NMDAR-Ab } \\
\text { encephalitis }\end{array}$ & AMPAR-Ab encephalitis & Neuromyelitis optica & $\begin{array}{l}\text { Glycine receptor anti- } \\
\text { body-associated disorder }\end{array}$ \\
\hline Typical symptoms & $\begin{array}{l}\text { Memory loss, seizures, } \\
\text { psychiatric or psycho- } \\
\text { logical disturbance }\end{array}$ & $\begin{array}{l}\text { Psychosis, bizarre } \\
\text { behaviours, mutism, } \\
\text { catatonia, movement } \\
\text { disorders, hypothalamic } \\
\text { dysfunction }\end{array}$ & $\begin{array}{l}\text { Memory loss, confusion, } \\
\text { seizures, agitation } \\
\text { Sometimes downbeat } \\
\text { nystagmus }\end{array}$ & $\begin{array}{l}\text { Optic nerve inflamma- } \\
\text { tion with visual loss } \\
\text { Spinal cord inflammation } \\
\text { leading to paralysis, loss } \\
\text { of sensation }\end{array}$ & $\begin{array}{l}\text { Excessive startle, rigidity, } \\
\text { myoclonic jerks }\end{array}$ \\
\hline Target & $\begin{array}{l}\text { Dendrotoxin-binding } \\
\text { CNS VGKC (KvI.I, } \\
\text { I. } 2,1.6)\end{array}$ & $\begin{array}{l}\text { NMDAR, probably } \\
\text { principally NRI }\end{array}$ & $\begin{array}{l}\text { GluRI/2 dimers, } \\
\text { epitopes on GluRI or } \\
\text { GluR2 }\end{array}$ & AQP4 & GlyR alpha la \\
\hline $\begin{array}{l}\text { Tumour association } \\
\text { or other pathology }\end{array}$ & Thymoma & $\begin{array}{l}\text { Ovarian teratomas in } \\
\text { young women }\end{array}$ & $\begin{array}{l}\text { Breast cancer, small-cell } \\
\text { lung cancer, thymoma }\end{array}$ & Very rare & Not common \\
\hline $\begin{array}{l}\text { Main pathogenic } \\
\text { mechanism }\end{array}$ & $\begin{array}{l}\text { Increased } \\
\text { internalisation }\end{array}$ & $\begin{array}{l}\text { Increased internalisation } \\
\text { Complement-mediated } \\
\text { mechanisms not } \\
\text { explored }\end{array}$ & $\begin{array}{l}\text { Increased internalisation } \\
\text { Complement-mediated } \\
\text { mechanisms not } \\
\text { explored }\end{array}$ & $\begin{array}{l}\text { Complement-mediated } \\
\text { mechanisms important } \\
\text { Increased internalisation } \\
\text { of AQP4 and increased } \\
\text { turnover of EAATI in } \\
\text { astrocytes }\end{array}$ & No evidence to date \\
\hline Disease course & $\begin{array}{l}\text { Self-limiting in most } \\
\text { cases } \\
\text { Immunotherapies } \\
\text { hasten recovery and } \\
\text { reduce long-term } \\
\text { disability }\end{array}$ & $\begin{array}{l}\text { Tumour cases do well } \\
\text { after removal and } \\
\text { treatments } \\
\text { Nontumour cases may } \\
\text { do less well and have a } \\
\text { tendency to relapse }\end{array}$ & $\begin{array}{l}\text { Responds to } \\
\text { immunotherapies but } \\
\text { has tendency to relapse }\end{array}$ & $\begin{array}{l}\text { Historically a severe } \\
\text { relapsing remitting dis- } \\
\text { ease with bad prognosis } \\
\text { May do better with } \\
\text { intensive } \\
\text { immunotherapies }\end{array}$ & $\begin{array}{l}\text { First patient described } \\
\text { returned to work after } \\
\text { intense immunotherapies }\end{array}$ \\
\hline $\begin{array}{l}\text { Intrathecal synthesis } \\
\text { of specific antibody } \\
\text { Normal }<1.5^{\mathrm{a}}\end{array}$ & $\begin{array}{l}\text { I. } 5 \text { to } 40 \text {, variable but } \\
\text { sometimes high }\end{array}$ & 10 to 30 , High & High & Little or none $(<\mid .5)$ & $\begin{array}{l}\text { I. } 5 \text { to }>50 \text {, variable but } \\
\text { sometimes very high }\end{array}$ \\
\hline
\end{tabular}

${ }^{a}$ This is calculated as (cerebrospinal fluid [CSF] titre of specific antibody/concentration of CSF lgG) / (serum titre of specific antibody/concentration of serum $\operatorname{lgG}$ ). Values above 1.5 are usually considered indicative of synthesis within the CSF compartment rather than the result of passive leakage. The values given are based on our unpublished experience and from data presented in $[18,2 \mathrm{I}]$. It needs to be appreciated that the normal serum IgG concentration is about 400 times higher than the normal CSF IgG concentration. Therefore, even in the presence of substantial intrathecal synthesis, the serum concentration of specific antibody will be higher than the CSF concentration. Ab, antibody; AMPAR, $\alpha$-amino-3-hydroxy-5-methyl-4-isoxazolepropionic acid receptor; AQP4, aquaporin-4; CNS, central nervous system; EAATI, excitatory amino acid transporter 2; GluR, glutamate receptor; GlyR, glycine receptor; NMDAR, $\mathrm{N}$-methyl-D-aspartate receptor; VGKC, voltage-gated potassium channel.

immunosuppression [29]; overall, there seems little doubt that the antibodies contribute to the pathology [22].

Finally, another receptor target is emerging in patients with rare spinal and brain stem syndromes. In one adult male who presented with excessive startle and progressive encephalomyelitis with rigidity and myoclonus (PERM), a form of stiff person syndrome, antibodies to glycine receptor alpha 1 pentamers (GlyR1s) were identified [30]. The GlyR1 antibodies disappeared with treatment and the patient made a substantial clinical recovery. These antibodies are now being found in other patients with related disorders (A Vincent, I Leite, H-M Meinck, unpublished data).

\section{Future directions}

There are some important lessons that arise out of these exciting advances. Once defined, the antibodies are best identified by binding to native proteins extracted from mammalian tissue in mild detergents (VGKCs), or better still to the native protein expressed in an appropriate human cell line (NMDARs, AMPARs, AQP4, GlyR), rather than to short peptides that do not represent the native conformation of the target antigen. The protein must be expressed on the cell surface and the cells should be unpermeabilised so that only cell surface-binding antibodies are detected (this ensures that they are potentially pathogenic, in contrast to those antibodies to intracellular components found in paraneoplastic disorders). Clustering of the antigen by use of intracellular scaffolding proteins can increase sensitivity and specificity as recently demonstrated for AChR antibodies [31]. In addition, the antibodies should be shown to bind to the extracellular surface of neurons or astrocytes cultured from mammalian tissues and to induce relevant biological changes in such cultures. In the future, one hopes that these studies will extend to examining the effects of these recently discovered antibodies on neuronal activity in brain slices in vitro and in animal models in vivo.

Considering the diversity of ion channels and receptors in the nervous system, it would be strange if there were no other autoimmune channelopathies to be discovered, 
diagnosed and treated. Until now, most of the target channels have been identified by a candidate approach, but if the target for binding to the cultured cells is sufficiently abundant, as appears to be the case for AMPARs [21], it is possible to immunoprecipitate the target using the relatively pure CSF IgG from the patients [21]; this technique has potential for identifying new targets in the future. Even the total patient plasma IgG can be used to identify antigens by this approach when a suitable cell preparation or cell line is identified [32].

In each of these diseases, CSF antibodies are found, and there is often evidence of high concentrations of CSFspecific antibody relative to CSF IgG concentration when compared with similar measurements in serum ('intrathecal synthesis', Table 2), but the absolute concentration of antibody is still higher in serum than in CSF. A major question, therefore, is whether the antibodies that are pathogenic come directly from the blood into the CNS parenchyma via a 'leaky' or damaged blood-brain barrier or whether the disorders require the presence of specific antibodies in the CSF. The latter could be the result of passive diffusion across the choroid plexus and/or intrathecal synthesis by $\mathrm{B}$ cells that have gained entry to the CNS and synthesise the antibodies in the intrathecal compartment. These considerations are not purely academic. Does intrathecal synthesis decrease with current systemic treatments and increase if the patient relapses? Do immune responses ever begin in the CNS and remain undetectable in the serum? And importantly, should drugs and therapies be specifically targeted to the CSF compartment rather than to the systemic immune system? These are just some of the questions that arise from the identification of these new autoimmune disorders, and the answers will likely come from both focused human studies and animal models.

\section{Abbreviations}

AChR, acetylcholine receptor; AMPAR, $\alpha$-amino-3hydroxy-5-methyl-4-isoxazolepropionic acid receptor; AQP4, aquaporin-4; Caspr2, contactin-associated protein 2; CNS, central nervous system; CSF, cerebrospinal fluid; EAAT2, excitatory amino acid transporter 2; GluR, glutamate receptor; GlyR1, glycine receptor alpha 1 pentamer; MRI, magnetic resonance imaging; PERM, progressive encephalomyelitis with rigidity and myoclonus; NMDAR, $\mathrm{N}$-methyl-D-aspartate receptor; NMO, Neuromyelitis optica; VGKC, voltage-gated potassium channel.

\section{Competing interests}

The author and her department receive royalties and income for antibody immunoassays.

\section{Acknowledgements}

I am very grateful to my colleagues Sarosh Irani, Sian Alexander, Luigi Zuliani, M Isabel Leite, Patrick Waters and Bethan Lang for their helpful comments and for providing their unpublished images and data for this review.

\section{References}

I. Vincent A: Unravelling the pathogenesis of myasthenia gravis. Nat Rev Immunol 2002, 2:797-804.

2. Vincent A, Lang B, Kleopa KA: Autoimmune channelopathies and related neurological disorders. Neuron 2006, 52: I23-38.

3. Hart IK, Waters C, Vincent A, Newland C, Beeson D, Pongs O, Morris C, Newsom-Davis J: Autoantibodies detected to expressed $\mathbf{K}^{+}$channels are implicated in neuromyotonia. Ann Neurol 1997, 41:238-46.

4. Vernino S, Low PA, Fealey RD, Stewart JD, Farrugia G, Lennon VA: Autoantibodies to ganglionic acetylcholine receptors in autoimmune autonomic neuropathies. N Engl J Med 2000, 343:847-55.

5. Rogers SW, Andrews PI, Gahring LC, Whisenand T, Cauley K, Crain B, Hughes TE, Heinemann SF, McNamara JO: Autoantibodies to glutamate receptor GluR3 in Rasmussen's encephalitis. Science 1994, 265:648-5I.

6. Watson R, Jiang Y, Bermudez I, Houlihan L, Clover L, McKnight K, Cross JH, Hart IK, Roubertie A, Valmier J, Hart Y, Palace J, Beeson D, Vincent A, Lang B: Absence of antibodies to glutamate receptor type 3 (GluR3) in Rasmussen encephalitis. Neurology 2004, 63:43-50.

7. Bien CG, Granata T, Antozzi C, Cross JH, Dulac O, Kurthen M, Lassmann H, Mantegazza R, Villemure JG, Spreafico R, Elger CE: Pathogenesis, diagnosis and treatment of Rasmussen encephalitis: a European consensus statement. Brain 2005, | 28:454-7|.

8. Buckley C, Oger J, Clover L, Tuzun E, Carpenter K, Jackson M, Vincent A: Potassium channel antibodies in two patients with reversible limbic encephalitis. Ann Neurol 200I, 50:73-8.

9. Vincent A, Buckley C, Schott JM, Baker I, Dewar BK, Detert N, Clover L, Parkinson A, Bien CG, Omer S, Lang B, Rossor MN, Palace J: Potassium channel antibody-associated encephalopathy: a potentially immunotherapy-responsive form of limbic encephalitis. Brain 2004, I 27:70I-I2.

10. Thieben MJ, Lennon VA, Boeve BF, Aksamit AJ, Keegan M, Vernino S: Potentially reversible autoimmune limbic encephalitis with neuronal potassium channel antibody. Neurology 2004, 62: I I7782.

II. Dalmau J, Rosenfeld MR: Paraneoplastic syndromes of the CNS. Lancet Neurol 2008, 7:327-40.

12. McKnight K, Jiang Y, Hart Y, Cavey A, Wroe S, Blank M, Shoenfeld Y, Vincent A, Palace J, Lang B: Serum antibodies in epilepsy and seizure-associated disorders. Neurology 2005, 65:1730-6.

13. Irani SR, Buckley C, Vincent A, Cockerell OC, Rudge P, Johnson MR, Smith S: Immunotherapy-responsive seizure-like episodes with potassium channel antibodies. Neurology 2008, 71:1647-8.

14. Liguori R, Vincent A, Clover L, Avoni P, Plazzi G, Cortelli P, Baruzzi A, Carey T, Gambetti P, Lugaresi E, Montagna P: Morvan's syndrome: peripheral and central nervous system and cardiac involvement with antibodies to voltage-gated potassium channels. Brain 200I, I 24:2417-26.

15. Kleopa KA, Elman LB, Lang B, Vincent A, Scherer SS: Neuromyotonia and limbic encephalitis sera target mature Shaker-type $\mathbf{K}^{+}$channels: subunit specificity correlates with clinical manifestations. Brain 2006, I29:I570-84.

16. Ances BM, Vitaliani R, Taylor RA, Liebeskind DS, Voloschin A, Houghton DJ, Galetta SL, Dichter M, Alavi A, Rosenfeld MR, Dalmau J: Treatment-responsive limbic encephalitis identified by 
neuropil antibodies: MRI and PET correlates. Brain 2005, I 28: | 764-77.

17. Dalmau J, Tuzun E, Wu HY, Masjuan J, Rossi JE, Voloschin A, Baehring JM, Shimazaki H, Koide R, King D, Mason W, Sansing LH, Dichter MA, Rosenfeld MR, Lynch DR: Paraneoplastic anti-Nmethyl-D-aspartate receptor encephalitis associated with ovarian teratoma. Ann Neurol 2007, 61:25-36.

FI000 Factor 3.0 Recommended

Evaluated by Angela Vincent 10 Apr 2007

18. Dalmau J, Gleichman AJ, Hughes EG, Rossi JE, Peng X, Lai M, Dessain SK, Rosenfeld MR, Balice-Gordon R, Lynch DR: AntiNMDA-receptor encephalitis: case series and analysis of the effects of antibodies. Lancet Neurol 2008, 7:1091-8.

FI000 Factor 3.0 Recommended

Evaluated by Angela Vincent 24 Oct 2008

19. Niehusmann P, Dalmau J, Rudlowski C, Vincent A, Elger CE, Rossi JE, Bien CG: Diagnostic value of $\mathrm{N}$-methyl-D-aspartate receptor antibodies in women with new-onset epilepsy. Arch Neurol 2009, 66:458-64.

20. DeGiorgio LA, Konstantinov KN, Lee SC, Hardin JA, Volpe BT, Diamond B: A subset of lupus anti-DNA antibodies crossreacts with the NR2 glutamate receptor in systemic lupus erythematosus. Nat Med 2001, 7:1 189-93.

FI000 Factor 3.0 Recommended

Evaluated by Angela Vincent I6 Jan 2002

21. Lai M, Hughes EG, Peng X, Zhou L, Gleichman AJ, Shu H, Matà S, Kremens D, Vitaliani R, Geschwind MD, Bataller L, Kalb RG, Davis R, Graus F, Lynch DR, Balice-Gordon R, Dalmau J: AMPA receptor antibodies in limbic encephalitis alter synaptic receptor location. Ann Neurol 2009, 65:424-34.

22. Jarius S, Paul F, Franciotta D, Waters P, Zipp F, Hohlfeld R, Vincent A, Wildemann B: Mechanisms of disease: aquaporin-4 antibodies in neuromyelitis optica. Nat Clin Pract Neurol 2008, 4:202-I4.

23. Lennon VA, Wingerchuk DM, Kryzer T], Pittock SJ, Lucchinetti CF, Fujihara K, Nakashima I, Weinshenker BG: A serum autoantibody marker of neuromyelitis optica: distinction from multiple sclerosis. Lancet 2004, 364:2106-12.

24. Lennon VA, Kryzer TJ, Pittock SJ, Verkman AS, Hinson SR: IgG marker of optic-spinal multiple sclerosis binds to the aquaporin-4 water channel. J Exp Med 2005, 202:473-7.

FI000 Factor 3.0 Recommended

Evaluated by Angela Vincent 05 Oct 2005

25. Hinson SR, Pittock SJ, Lucchinetti CF, Roemer SF, Fryer JP, Kryzer TJ, Lennon VA: Pathogenic potential of IgG binding to water channel extracellular domain in neuromyelitis optica. Neurology 2007, 69:2221-31.

FI000 Factor 3.0 Recommended

Evaluated by Angela Vincent 18 Dec 2007

26. Hinson SR, Roemer SF, Lucchinetti CF, Fryer JP, Kryzer TJ, Chamberlain JL, Howe CL, Pittock SJ, Lennon VA: Aquaporin-4binding autoantibodies in patients with neuromyelitis optica impair glutamate transport by down-regulating EAAT2. J Exp Med 2008, 205:2473-8I.

FI000 Factor 3.0 Recommended

Evaluated by Charlotte Teunissen 06 Nov 2008

27. Misu T, Fujihara K, Kakita A, Konno H, Nakamura M, Watanabe S, Takahashi T, Nakashima I, Takahashi H, Itoyama Y: Loss of aquaporin 4 in lesions of neuromyelitis optica: distinction from multiple sclerosis. Brain 2007, I 30: I 224-34.

28. Roemer SF, Parisi JE, Lennon VA, Benarroch EE, Lassmann H, Bruck W, Mandler RN, Weinshenker BG, Pittock SJ, Wingerchuk DM, Lucchinetti CF: Pattern-specific loss of aquaporin-4 immunoreactivity distinguishes neuromyelitis optica from multiple sclerosis. Brain 2007, I30: I | 94-205.

FI000 Factor 3.0 Recommended Evaluated by Angela Vincent 04 Jun 2007

29. Jarius S, Aboul-Enein F, Waters $P$, Kuenz B, Hauser A, Berger $T$, Lang $W$, Reindl $M$, Vincent $A$, Kristoferitsch W: Antibody to aquaporin-4 in the long-term course of neuromyelitis optica. Brain 2008, I 3 I:3072-80.

30. Hutchinson M, Waters P, McHugh J, Gorman G, O'Riordan S, Connolly S, Hager H, Yu P, Becker CM, Vincent A: Progressive encephalomyelitis, rigidity, and myoclonus: a novel glycine receptor antibody. Neurology 2008, 71:129|-2.

3I. Leite MI, Jacob S, Viegas S, Cossins J, Clover L, Morgan BP, Beeson D, Willcox N, Vincent A: IgGI antibodies to acetylcholine receptors in 'seronegative' myasthenia gravis. Brain 2008, | 3 |: | $940-52$.

FI000 Factor 3.0 Recommended Evaluated by Steven Burden 16 Jan 2009

32. Littleton E, Dreger M, Palace J, Vincent A: Immunocapture and identification of cell membrane protein antigenic targets of serum autoantibodies. Mol Cell Proteomics 2009, 8: 1688-96.

33. Schimmel M, Bien CG, Vincent A, Schenk W, Penzien J: Successful treatment of anti-N-Methyl-D-aspartate receptor encephalitis presenting with catatonia. Arch Dis Child 2009, 94:314-6.

34. Waters P, Jarius S, Littleton E, Leite MI, Jacob S, Gray B, Geraldes R, Vale T, Jacob A, Palace J, Maxwell S, Beeson D, Vincent A: Aquaporin-4 antibodies in neuromyelitis optica and longitudinally extensive transverse myelitis. Arch Neurol 2008, 65:913-9. 